\title{
PASSION FRUIT SEED MEAL AT GROWING AND FINISHING PIG (30-90 KG) FEEDING
}

\author{
Farelo da semente de maracujá na alimentação de \\ suínos em crescimento e terminação $(30-90 \mathrm{~kg})$
}

\author{
Dani Perondi' ${ }^{1}$ Ivan Moreira ${ }^{2}$, Paulo Cesar Pozza ${ }^{2}$, Paulo Levi de Oliveira Carvalho², \\ Tiago Junior Pasquetti², Laura Marcela Diaz Huepa ${ }^{2}$
}

\begin{abstract}
The passion fruit seed is a byproduct of the extraction of the passion fruit pulp and can be used for feeding to pigs. Two experiments were conducted (digestibility and performance) to evaluate the use of the passion fruit seed meal in feed for growing and finishing pigs. A digestibility trial was conducted with growing and finishing pigs, in which the passion fruit seed meal (PSM) replaced the reference diet ( $0 \%$ PSM) in levels of 4, 8, 12 and 16\%. Thirty barrows were used with average weight of $36.85 \pm 4.19$. The PSF showed DE and ME of 3.244 and $3.223 \mathrm{Mcal} / \mathrm{kg}$, respectively. In the performance trial, were used 150 pigs, which 75 in the growing phase and 75 pigs in the finishing, with initial body weight of $30.63 \pm 1.49$ and final of $60.38 \pm 4.75 \mathrm{~kg}$ and $60.40 \pm 1.50$ and $90.02 \pm 4.84 \mathrm{~kg}$, respectively. Five diets were used, with four inclusion levels of PSM (4, 8, 12 e $16 \%)$ and one control diet $(0 \%$ of PSM). The PSM levels did not influence $(\mathrm{P}>0.05)$ the performance variables. In the growing pigs, serum levels of cholesterol increased linearly with $(\mathrm{P}<0.05)$ inclusion levels of PSM. Quantitative of carcass traits and meat quality were not affected $(\mathrm{P}>0.05)$ by increasing levels of PSM in the diets. We conclude that the PSM can be used up to $16 \%$ in growing and finishing pigs diets.
\end{abstract}

Index terms: Co-product, digestibility, nutritional value, carcass.

\section{RESUMO}

A semente do maracujá é um subproduto da extração da polpa do maracujá, podendo ser utilizado na alimentação dos suínos. Foram conduzidos dois experimentos (digestibilidade e desempenho), objetivando avaliar a utilização do farelo da semente de maracujá na alimentação de suínos em crescimento e terminação. Inicialmente foi realizado um ensaio de digestibilidade com suínos em crescimento e terminação, em que o farelo da semente de maracujá (FSM) substituiu a ração referência (0\% FSM)

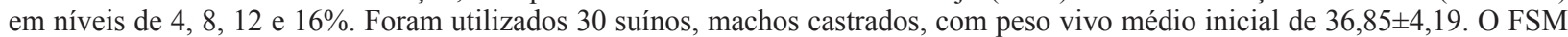
apresentou ED e EM de 3.244 e $3.223 \mathrm{Mcal} / \mathrm{kg}$, respectivamente. No ensaio de desempenho, foram utilizados 150 suínos, sendo 75 na fase de crescimento e 75 na fase de terminação, com peso vivo inicial de 30,63 $\pm 1,49$ e final de $60,38 \pm 4,75 \mathrm{~kg}$ e $60,40 \pm 1,50$ e $90,02 \pm 4,84 \mathrm{~kg}$, respectivamente. Foram utilizadas cinco dietas, sendo quatro níveis de inclusão do FSM (4, 8, 12 e $16 \%$ e uma ração testemunha $(0 \%$ do FSM). Os níveis do FSM não influenciaram $(\mathrm{P}>0,05)$ as variáveis de desempenho. Na fase de crescimento, os níveis séricos de colesterol aumentaram linearmente $(\mathrm{P}<0,05)$ com os níveis de inclusão do FSM. As variáveis quantitativas de carcaça e qualitativas da carne não foram influenciadas $(\mathrm{P}>0,05)$ pelos níveis crescentes do FSM nas dietas. Conclui-se que o FSM pode ser utilizado em até $16 \%$ em dietas de suínos em crescimento e terminação.

Termos para indexação: Subproduto, digestibilidade, valor nutricional, carcaça.

\section{INTRODUCTION}

World production of pork meat reached, in 2011, the total of 101.127 million metric tons, in which China was the largest producer (49.500), followed by the European Union (22.530), the United States (10.278) and the Brazil (3.227) in fourth position (ABIPECS, 2012).

The pig production can be impaired by high production costs, mainly corn and soybean meal. These two ingredients, due its composition and nutritional value, are the base for feed of monogastric animals, in especially pigs. Thus, there is a need to search new sources of alternative food and quantify the animal responses, in performance and economic terms. One alternative is the introduction of co-products industry fruits (juice and pulp) in the diet, however, some of these co-products still lack studies about its adequate nutritional composition, as well as its economic viability.

The Brazil, because is a tropical country, has ideal conditions for the production of a series of fruits, including passion fruit, being the largest world producer. In 2010, Brazil produced about 920 tons of passion fruit, in which the northeast region produced approximately $76 \%$ of the national production (IBGE, 2011).

${ }^{1}$ Universidade Estadual Paulista/UNESP - Faculdade de Ciências Agrárias e Veterinárias/FCAV - Via de Acesso Paulo Donato Castellane - s/n 14884.900 - Jaboticabal - SP - Brasil - daniel.prd@zootecnista.com.br

'Universidade Estadual de Maringá/UEM - Departamento de Zootecnia - Maringá - PR - Brasil

Received in november 29, 2013 and approved in april 19, 2014

Ciênc. Agrotec., Lavras, v.38, n.4, p.390-400, jul./ago., 2014 
According to Ferrari, Colussi and Ayub (2004) only $23.20 \%$ of passion fruit is availed during the juice production, and the remainder $(76.80 \%)$ is residues, in which the seed represents 6 to $12 \%$ of the total weight of the fruit.

Chau and Huang (2004) observed that the seed of passion fruit showed high levels of ether extract $(24.50 \%)$ and crude protein $(8.25 \%)$, which is similar to corn. Ariki et al. (1977) found value of $1.635 \mathrm{Mcal} / \mathrm{kg}$ of metabolizable energy in passion fruit seed meal for broiler chickens. Using passion fruit seed meal in diets for broilers Togashi et al. (2008) found that the inclusion of up $8 \%$ did not impair the performance and carcass traits of birds. Likewise Ariki et al. (1977) found no loss in the performance of the broilers.

Thus, because of the scarcity of scientific information about the passion fruit seed meal in feed for pigs, this work was conducted to determine the nutritional value and verify the performance, blood biochemical variables, quantitative carcass traits, meat quality and economic viability in growing and finishing pigs.

\section{MATERIAL AND METHODS}

The experiments were conducted in the pig sector of Iguatemi Experimental Farm, owned by the Center for Agricultural Sciences of Maringá State University. The co-product of passion fruit, (Passiflora edulis) was ceded by the fruit industry - Fruteza - Ltda. The material studied was obtained from the extraction of the pulp and passion fruit peel, and stored in cold chambers $\left(-18^{\circ} \mathrm{C}\right)$. The co-product had $60 \%$ of moisture and was subjected to dehydration. The dehydration was done in the sun, in a cemented area, until the material reaches ideal humidity for storage. The material was ground in a hammer mill (with sieve containing holes of $2.5 \mathrm{~mm}$ of diameter), and thus obtaining the PSM (passion fruit seed meal).

Analyses of dry matter, organic matter, ash, crude protein, neutral detergent fiber, acid detergent fiber, $\mathrm{pH}$, crude fat and gross energy were carried out according to the procedures described by Silva and Queiroz (2005).

In the digestibility trial, 30 barrows of commercial line, average $36.85 \pm 4.19 \mathrm{~kg}$ of body weight, were allotted in a randomized block design with five treatments and six replications, and were individually housed in metabolism cages type "Pekas". The PSM replaced (based on dry matter) the basal diet at levels of $4,8,12$ and $16 \%$, resulting in four test diets and one reference diet ( $0 \%$ of PSM). The reference diet, based on corn and soybean meal, was calculated to meet the requirements proposed by Rostagno et al. (2011).
The experimental period consisted of 15 days (ten days of adaptation and five days of total collection of feces and urine). The feeding and collection of feces and urine were performed according to the procedures described by Sakomura and Rostagno (2007). In the collection period, the amount of feed provided per animal was calculated on the basis of metabolic body weight $\left({ }^{0.75} \mathrm{~kg}\right)$ and the average consumption recorded in the adaptation period.

The digestibility of dry matter, gross energy and metabolization coefficient of organic matter, crude protein, neutral detergent fiber, acid detergent fiber and crude fat were calculated according to Matterson, Potter and Stutz (1965). The digestible energy (DE) and metabolizable (ME) were estimated by regression analysis (Adeola; Ileleji, 2009).

In the growing pigs performance trial, 75 crossbred pigs from a commercial line were used, with average initial body weight of $30.63 \pm 1.49$ and final of $60.38 \pm 4.75 \mathrm{~kg}$, and 75 pigs in the finishing with average initial body weight of $60.40 \pm 1.50$ and final of $90.02 \pm 4.84 \mathrm{~kg}$.

The treatments consisted of five diets with four inclusion levels of PSM (4, 8, 12 and 16\%) and a control diet ( $0 \%$ to PSM). The diets, based on corn and soybean meal (Table 1 and 2), were formulated to meet the requirements proposed by Rostagno et al. (2011) for pigs during the growing $(30-60 \mathrm{~kg})$ and finishing (60-90 $\mathrm{kg})$ pigs.

The pigs were allotted in a randomized block design, with 15 replications in the time and one pig per experimental unit. The treatments consisted of four inclusion levels $(4,8,12$ and 16\%) of PSM and a control $\operatorname{diet}(0 \%$ of PSM). The animals were housed in facilities, covered with fiber cement tiles, consisting of 40 pens. The animals were weighed at the beginning and at the end of the experiment, and the total feed intake was computed, in order to calculate the daily feed intake, daily weight gain and feed conversion for each experimental unit. At the end of the growing and finishing pigs, backfat thickness and loin depth were measured at the position P2, using the apparatus Sono-Grader $\left(\right.$ Renco $\left.^{\circledR}\right)$.

At the beginning of the trial, in the growing and finishing pigs, blood samples were harvest for analysis of plasma urea nitrogen (PUN). The results obtained in the beginning were used as a "covariate" for the statistical analysis of PUN at the end of the trial. For glucose, triglycerides and cholesterol the procedures were performed as Moreno et al. (1997).

At the end of the finishing pigs, all pigs were fasted for an average of 24 hours until the slaughter. 
Table 1 - Centesimal and chemical composition of diets containing increasing levels of passion fruit seed meal (PSM) for pigs, during the growing $(30-60 \mathrm{~kg})$.

\begin{tabular}{|c|c|c|c|c|c|}
\hline \multirow[b]{2}{*}{ Ingredients (\%) } & \multicolumn{5}{|c|}{ Inclusion levels of PSM (\%) } \\
\hline & 0 & 4 & 8 & 12 & 16 \\
\hline Corn & 73.886 & 70.140 & 66.395 & 62.651 & 58.905 \\
\hline Soybean meal & 22.699 & 22.375 & 22.052 & 21.728 & 21.404 \\
\hline Passion fruit seed meal & - & 4.000 & 8.000 & 12.000 & 16.000 \\
\hline Dicalcium phophate & 1.160 & 1.155 & 1.149 & 1.144 & 1.139 \\
\hline Limestone & 0.691 & 0.692 & 0.692 & 0.692 & 0.727 \\
\hline Soybean oil & 0.507 & 0.562 & 0.617 & 0.672 & 0.692 \\
\hline Sodium chloride & 0.400 & 0.400 & 0.400 & 0.400 & 0.400 \\
\hline Mineral vitamin suplement ${ }^{1}$ & 0.300 & 0.300 & 0.300 & 0.300 & 0.300 \\
\hline L-Lysine $\mathrm{HCl}$ & 0.250 & 0.259 & 0.268 & 0.276 & 0.285 \\
\hline DL- Methionine & 0.058 & 0.062 & 0.065 & 0.069 & 0.073 \\
\hline L-Threonine & 0.039 & 0.046 & 0.052 & 0.058 & 0.065 \\
\hline Antioxidant $^{2}$ & 0.010 & 0.010 & 0.010 & 0.010 & 0.010 \\
\hline \multicolumn{6}{|l|}{ Values calculated $^{3}$} \\
\hline Metabolizable energy, Mcal/kg & 3.230 & 3.230 & 3.230 & 3.230 & 3.230 \\
\hline Crude protein $(\%)$ & 16.48 & 16.53 & 16.57 & 16.62 & 16.66 \\
\hline Calcium (\%) & 0.609 & 0.609 & 0.609 & 0.609 & 0.609 \\
\hline Available phosphorus (\%) & 0.318 & 0.318 & 0.318 & 0.318 & 0.318 \\
\hline Digestible lysine (\%) & 0.901 & 0.901 & 0.901 & 0.901 & 0.901 \\
\hline Digestible met+cist. (\%) & 0.540 & 0.540 & 0.540 & 0.540 & 0.540 \\
\hline Digestible threonine (\%) & 0.585 & 0.585 & 0.585 & 0.585 & 0.585 \\
\hline Digestible tryptophan (\%) & 0.162 & 0.162 & 0.162 & 0.162 & 0.162 \\
\hline Neutral detergent fiber $(\%)$ & 11.944 & 13.533 & 15.122 & 16.711 & 18.300 \\
\hline Acid detergent fiber $(\%)$ & 4.329 & 6.146 & 7.963 & 9.780 & 11.597 \\
\hline Crude fat $(\%)$ & 3.585 & 4.276 & 4.966 & 5.657 & 6.313 \\
\hline Feed cost $\mathrm{R} \$ / \mathrm{kg}$ & 0.802 & 0.801 & 0.799 & 0.797 & 0.796 \\
\hline
\end{tabular}

${ }^{1}$ Vitamin and mineral premix for growing pigs (Vit A, 2,300,000 IU; Vit D3, 466,667 IU; Vit E - 5,000 IU; Vit K3, 667 mg ; Vit B1, $333 \mathrm{mg}$; Vit B2, 1,000 mg ;Vit B6, $400 \mathrm{mg}$; Vit B12, 4,000 $\mu \mathrm{g}$; Pholic Acid, $67 \mathrm{mg}$; Niacin, 6,660 mg; Ac. Pantothenic, 4,000 mg; Biotin, 17 mg; Choline ,43 g; Iron 26,667 mg; Copper, 41,667 mg; Cobalt, 183 mg; Manganese, 16,667 mg; Zinc, 26,667 mg; Selenium, $67 \mathrm{mg}$; Iodine, $267 \mathrm{mg}$; Antioxidant 27 g; Vehicle q.s.p., 1,000 g); ${ }^{2} \mathrm{BHT} ;{ }^{3}$ Calculated based on Rostagno et al. (2011) and/or determined. Source: Elaboration of the authors

Carcasses were chilled ( 1 to $2^{\circ} \mathrm{C}$ ) for 24 hours and then, were subjected to quantitative evaluation, according to the Brazilian Method of Carcass Classification Swine MBCC (Bridi; Silva, 2009).

The economic viability of PSM was done with basis on prices of raw material that were obtained in the local market, and then, the costs of feed per $\mathrm{Kg}$ of live weight gain were calculated according to Bellaver et al. (1985). It was also calculated the Economic Efficiency Index (EEI) and the Cost Index (CI), according to the methodology proposed by Gomes et al. (1991). The values obtained were subjected to analysis of variance, adopting the following statistical model: $Y i j k m=\mathrm{M}+\mathrm{Bi}+\mathrm{Sj}+\mathrm{Nk}+$ eijkm where Yijkm $=$ observation of animals $\mathrm{m}$, inside the block $\mathrm{i}$, 
the inclusion level of $\mathrm{k}, \mathrm{M}=$ constant associated with all observations, $\mathrm{Bi}=$ effect of block, where $\mathrm{i}=1,2,3 \ldots 15$, $\mathrm{Sj}=$ effect of sex $\mathrm{j}(1=$ female $2=$ male $) ; \mathrm{Nk}=$ effect of the levels the PSM, where $\mathrm{k}=0,4,8,12,16 \%$; eijkm = random error associated with the observation. The degrees of freedom, related to the inclusion levels of PSM, were broken down into orthogonal polynomials to obtain the regression equations. To analyse data, the initial weight of the pigs was used as a covariate.

\section{RESULTS AND DISCUSSION}

The digestibility coefficients of ether extract of PSM (Table 3) showed intermediate values compared to indicated by Rostagno et al. (2011), for corn (90\%) and sorghum $(80 \%)$.

The digestible coefficient of organic matter of PSM (58.24\%) showed lower value than those described by Rostagno et al. (2011), for corn (90\%) and sorghum

Table 2 - Centesimal and chemical composition of diets containing increasing levels of passion fruit seed meal (PSM) for pigs, during the finishing $(60-90 \mathrm{~kg})$.

\begin{tabular}{|c|c|c|c|c|c|}
\hline \multirow[b]{2}{*}{ Ingredients (\%) } & \multicolumn{5}{|c|}{ Inclusion levels of PSM (\%) } \\
\hline & 0 & 4 & 8 & 12 & 16 \\
\hline Corn & 74.819 & 71.073 & 67.329 & 63.586 & 59.840 \\
\hline Soybean meal & 22.720 & 22.397 & 22.072 & 21.749 & 21.426 \\
\hline Passion fruit seed meal & - & 4.000 & 8.000 & 12.000 & 16.000 \\
\hline Dicalcium phosphates & 0.833 & 0.827 & 0.822 & 0.816 & 0.811 \\
\hline Limestone & 0.633 & 0.634 & 0.634 & 0.634 & 0.634 \\
\hline Soybean oil & 0.175 & 0.230 & 0.285 & 0.340 & 0.395 \\
\hline Sodium chloride & 0.400 & 0.400 & 0.400 & 0.400 & 0.400 \\
\hline Vitamin and mineral premix ${ }^{1}$ & 0.150 & 0.150 & 0.150 & 0.150 & 0.150 \\
\hline L-Lysine $\mathrm{HCl}$ & 0.190 & 0.199 & 0.208 & 0.216 & 0.225 \\
\hline DL- Methionine & 0.046 & 0.049 & 0.053 & 0.056 & 0.060 \\
\hline L-Threonine & 0.024 & 0.031 & 0.037 & 0.043 & 0.050 \\
\hline Antioxidant $^{2}$ & 0.010 & 0.010 & 0.010 & 0.010 & 0.010 \\
\hline \multicolumn{6}{|l|}{ Values calculated $^{3}$} \\
\hline Metabolizable energy, Mcal/kg & 3.230 & 3.230 & 3.230 & 3.230 & 3.230 \\
\hline Crude protein $(\%)$ & 16.50 & 16.54 & 16.59 & 16.64 & 16.68 \\
\hline Calcium (\%) & 0.507 & 0.507 & 0.507 & 0.507 & 0.507 \\
\hline Available phosphorus (\%) & 0.258 & 0.258 & 0.258 & 0.258 & 0.258 \\
\hline Digestible lysine (\%) & 0.857 & 0.857 & 0.857 & 0.857 & 0.857 \\
\hline Digestible met + cist. (\%) & 0.531 & 0.531 & 0.531 & 0.531 & 0.531 \\
\hline Digestible threonine (\%) & 0.574 & 0.574 & 0.574 & 0.574 & 0.574 \\
\hline Digestible tryptophan (\%) & 0.162 & 0.162 & 0.162 & 0.162 & 0.162 \\
\hline Neutral detergent fiber (\%) & 12.058 & 13.647 & 15.236 & 16.826 & 18.414 \\
\hline Acid detergent fiber $(\%)$ & 4.362 & 6.179 & 7.996 & 9.813 & 11.630 \\
\hline Crude fat $(\%)$ & 3.289 & 3.980 & 4.670 & 5.361 & 6.051 \\
\hline Feed cost, $\mathrm{R} \$ / \mathrm{kg}$ & 0.769 & 0.767 & 0.766 & 0.764 & 0.763 \\
\hline
\end{tabular}

${ }^{1}$ Vitamin and mineral premix for fishing pigs (Vit A, 2,666,660 IU; Vit D3, 533,300 IU ; Vit E, 4,667 IU ; Vit K3, 1,200 mg ; Vit B1, 200 mg ; Vit B2, 13.336 mg; Vit B6, 133 mg; Vit B12, 6,667 $\mu$ g; Pholic Acid, 34 mg; Niacin, 10,000 mg; Pantothenic, 666,666 mg; Biotin, 20 mg; Choline, 62 g; Iron, 40 mg; Copper, 86,805 mg; Cobalt, 334 mg; Manganese, 30,000 mg; Zinc, 46,666 mg; Selenium, $67 \mathrm{mg}$; Iodine, $400 \mathrm{mg}$; Antioxidant, 40 g; Vehicle q.s.p., 1,000 g); ${ }^{2} \mathrm{BHT} ;{ }^{3}$ Calculate based on Rostagno et al. (2011) and/ or determined. Source: Elaboration of the authors. 
(75.53\%), respectively. These differences observed in the nutrients digestibility of PSM, compared to corn and sorghum, could be due to the elevated amount of NDF. According to Bertechini (2012) the fraction of fiber, when presents in the diets for monogastric, impair the nutrient digestibility, due to increasing the speed of intestinal transit, which reduce the use of nutrients.

The DC and MC of gross energy for PSM (Table 3) were lower than those reported by Rostagno et al. (2011), for corn and sorghum, (87.88 and $84.77 \%$, respectively). Probably, the high content of NDF for PSM decreased the gross energy digestibility and metabolization. According to Noblet and Perez (1993) the fiber reduces the nutrients digestibility of ingredients in pig diets.

The highest DC was obtained for fat crude, showing that the PSM can be a good energetic source. This fact is particularly interesting, since our study aims to use the PSM as an alternative ingredient, replacing part of corn in pig diets.

The PSM presented metabolizable energy of 3.223 $\mathrm{Mcal} / \mathrm{kg}$ (Table 3), based in natural matter. This ME value is higher than those observed for passion fruit seed meal (1.635 Mcal $/ \mathrm{kg}$ ), found by Ariki et al. (1977). Possibly, the lowest crude fat content verified by this author was the responsible for lower ME value for passion fruit seed meal, compared to the value obtained in our study, for PSM.

According to nutrients digestibility and metabolizable energy for PSM, is possible to use this ingredient as a substitute of part of corn in pig diets, in growing and finishing pigs, because the ME value is similar to corn.

For the growing and finishing pigs, there was no effect $(\mathrm{P}>0.05)$ of inclusion levels of PSM on daily feed intake, average daily gain, feed conversion, backfat thickness and loin depth (Table 4). This means that, regardless of the inclusion levels of PSM (until 16\%), the pig performance is not impaired, in which together with nutrients digestibility obtained for PSM, suggest that this feedstuffs can be energy source for growing and finishing pigs.

Additionally, the use of soybean oil in the diet, in order to adjust the diet to be isocaloric, may have helped to maintain constant performance of the animals, because according to Bertechini (2012), the use of fats and oils in pig diets has a number benefits, known as "specific dynamic

Table 3 - Apparent digestibility coefficients (DC), metabolization coefficient (MC) and digestible values of nutrients of passion fruit seed meal (PSM) used on growing and finishing pigs feeding.

\begin{tabular}{lc}
\hline Digestibility coefficients, \% & \\
\hline DC Dry matter & 59.23 \\
DC Crude energy & 60.64 \\
MC Crude energy & 60.23 \\
DC Organic matter & 58.24 \\
DC Crude protein & 73.80 \\
DC Neutral detergent fiber & 62.91 \\
DC Acid detergent fiber & 56.57 \\
DC Crude fat & 83.23 \\
\hline Digestible nutrients & \\
\hline Digestible Dry matter $(\mathrm{g} / \mathrm{kg})$ & 52.92 \\
Digestible Energy $(\mathrm{Mcal} / \mathrm{kg})$ & 3.244 \\
Metabolizable Energy $(\mathrm{Mcal} / \mathrm{kg})$ & 3.223 \\
Digestible Organic matter $(\mathrm{g} / \mathrm{kg})$ & 50.52 \\
Digestible Crude protein $(\mathrm{g} / \mathrm{kg})$ & 9.00 \\
Digestible Neutral detergent fiber $(\mathrm{g} / \mathrm{kg})$ & 32.72 \\
Digestible Acid detergent fiber $(\mathrm{g} / \mathrm{kg})$ & 27.85 \\
Digestible Crude fat $(\mathrm{g} / \mathrm{kg})$ & 16.19 \\
\hline
\end{tabular}


action of fat." Results to this study were similar to observed previously by Togashi et al. (2008) and Ariki et al. (1977), who using the passion fruit seed meal up to $8 \%$ in diets of broiler chicken, found no effect on animal performance.

Considering the blood biochemical variables, in growing pigs (Table 5), no effect of PSM were observed $(\mathrm{P}>0.05)$ on glucose, triglycerides and plasma urea nitrogen (PUN) levels. On the other hand, the cholesterol increased linearly $(\mathrm{P}<0.05)$. In the finishing pigs, there was no effect $(\mathrm{P}>0.05)$ of PSM levels on blood biochemical variables.

Plasma levels of glucose, triglycerides, cholesterol and NUP, are within the range considered normal for the growing and finishing pigs (Moreno et al., 1997). The increase of cholesterol during growing pigs may have been caused by increasing crude fat in the diet (Table 1). According to Nelson and Cox (2011) the dietetic conditions, such as the excessive crude fat may increase the circulating levels of plasma cholesterol. In this study, the cholesterol values were different than those found by Togashi et al. (2008), who using inclusion levels of up to $8 \%$ of PSM, in diets for broilers chickens, observed no change in plasma cholesterol. However, were used lower levels of inclusion (4 and $8 \%$ ) and furthermore, the PSM showed lower value of crude fat (4.62\%).
The results obtained for PUN, in our study, suggest that the PSM not impair the protein metabolism, maintaining the quality of protein in the diets. This reflects the adequate supply of amino acids, in quantity and quality in the diets (Coma; Carrion; Zimmerman, 1995).

The utilization of increasing levels of PSM in the diets did not affect $(\mathrm{P}>0.05)$ the quantitative carcass traits and qualitative characteristics of pork meat, for finishing pigs (Tables 6 and 7).

It was verified that the PSM increased the NDF content of the diets for approximately $18 \%$ (Tables 1 and 2 ), in the highest level of inclusion, however, caused no changes in carcass traits of pigs. Likewase, Gomes et al. (2007) found that the increase in NDF content of pig diets did not impair the carcass traits, corroborating the findings in our study. Similar results to this study, for carcass traits, were found by Togashi et al. (2008) using passion fruit seed meal up to $8 \%$ in diets for broiler chickens.

Concerning the economic analysis (Table 8) there was no effect $(\mathrm{P}>0.05)$ of inclusion levels of PSM, during the growing and finishing pigs, on feed cost per kilogram of live weight gain. Although no statistical analysis was performed for the EEI and IC, its best values were observed in the inclusion level of $16 \%$ of PSM. This result suggests that the PSM can be used up to $16 \%$ in diets for pigs, in growing and finishing pigs.

Table 4 - Daily feed intake (DFI), average daily gain (ADG), feed conversion (FC), backfat thickness (BT) and loin depth (LP) of growing and finishing (30-90 kg) pigs fed on diets contain different inclusion levels of passion fruit seed meal (PSM).

\begin{tabular}{|c|c|c|c|c|c|c|c|c|}
\hline \multirow{2}{*}{ Item } & \multicolumn{5}{|c|}{ Inclusion levels of PSM, \% } & \multirow{2}{*}{ Mean $\pm \mathrm{SE}^{1}$} & \multicolumn{2}{|c|}{$p$-value } \\
\hline & 0 & 4 & 8 & 12 & 16 & & $\operatorname{Lin}^{2}$ & Qua $^{3}$ \\
\hline \multicolumn{9}{|c|}{ Growing } \\
\hline DFI (kg) & 2.01 & 2.04 & 2.09 & 2.15 & 2.10 & $2.08 \pm 0.028$ & 0.13 & 0.51 \\
\hline $\mathrm{ADG}(\mathrm{kg})$ & 0.87 & 0.87 & 0.90 & 0.90 & 0.90 & $0.89 \pm 0.015$ & 0.28 & 0.81 \\
\hline $\mathrm{FC}(\mathrm{kg} / \mathrm{kg})$ & 2.31 & 2.36 & 2.31 & 2.42 & 2.33 & $2.34 \pm 0.028$ & 0.62 & 0.60 \\
\hline $\mathrm{BT}(\mathrm{mm})$ & 8.80 & 8.64 & 8.73 & 9.20 & 7.85 & $8.64 \pm 0.136$ & 0.16 & 0.07 \\
\hline $\mathrm{LP}(\mathrm{mm})$ & 39.13 & 40.26 & 40.66 & 39.26 & 40.80 & $40.02 \pm 0.641$ & 0.61 & 0.85 \\
\hline \multicolumn{9}{|c|}{ Finishing } \\
\hline DFI $(\mathrm{kg})$ & 2.68 & 2.77 & 2.70 & 2.73 & 2.67 & $2.71 \pm 0.036$ & 0.79 & 0.45 \\
\hline ADG (kg) & 0.90 & 0.94 & 0.93 & 0.88 & 0.90 & $0.91 \pm 0.015$ & 0.55 & 0.56 \\
\hline $\mathrm{FC}(\mathrm{kg} / \mathrm{kg})$ & 3.07 & 3.00 & 2.91 & 3.12 & 2.99 & $3.02 \pm 0.036$ & 0.86 & 0.58 \\
\hline $\mathrm{BT}(\mathrm{mm})$ & 10.86 & 11.50 & 10.93 & 11.03 & 10.86 & $11.04 \pm 0.259$ & 0.82 & 0.66 \\
\hline $\mathrm{LP}(\mathrm{mm})$ & 51.33 & 51.21 & 49.86 & 49.66 & 52.40 & $50.89 \pm 0.627$ & 0.89 & 0.19 \\
\hline
\end{tabular}

${ }^{1}$ Standard error; ${ }^{2}$ Linear effect of PSM levels; ${ }^{3}$ Quadratic effect of PSM levels. 
The increase of soybean oil and some synthetic amino acids in the diets, contributed to increases the cost of diets. Thus, the viability of using the passion fruit seed meal, in pig diets, will also depend on the price of these ingredients. These results suggest that the passion fruit seed meal, with its price of 0.90 or less in relation to the price of corn, it becomes economically viable for pigs, in the growing and finishing.

Table 5 - Blood biochemical variables ( $\mathrm{mg} / \mathrm{dl})$ of glucose, triglycerides, cholesterol and plasma urea nitrogen (PUN) of growing (30-60 kg) and finishing $(60-90 \mathrm{~kg})$ pigs feed on diets contain different inclusion levels of passion fruit seed meal (PSM).

\begin{tabular}{|c|c|c|c|c|c|c|c|c|}
\hline \multirow{2}{*}{ Item } & \multicolumn{5}{|c|}{ Inclusion levels of PSM (\%) } & \multirow{2}{*}{ Mean $\pm \mathrm{SE}^{1}$} & \multicolumn{2}{|c|}{$p$-value } \\
\hline & 0 & 4 & 8 & 12 & 16 & & Linear & Quadratic \\
\hline \multicolumn{9}{|c|}{ Growing } \\
\hline Glucose & 82.10 & 78.00 & 81.15 & 79.57 & 85.14 & $81.22 \pm 1.409$ & 0.40 & 0.17 \\
\hline Triglycerides & 40.04 & 42.88 & 37.30 & 43.53 & 39.58 & $40.74 \pm 1.522$ & 0.97 & 0.87 \\
\hline Cholesterol & 64.14 & 69.03 & 79.79 & 71.78 & 72.25 & $69.53 \pm 1.449$ & 0.04 & 0.49 \\
\hline NUP & 11.08 & 12.14 & 11.44 & 11.79 & 13.07 & $11.90 \pm 0.320$ & 0.10 & 0.57 \\
\hline \multicolumn{9}{|c|}{ Finishing } \\
\hline Glucose & 84.50 & 78.86 & 84.60 & 84.25 & 82.46 & $82.93 \pm 1.424$ & 0.89 & 0.89 \\
\hline Triglycerides & 38.66 & 38.00 & 35.46 & 32.26 & 36.23 & $36.12 \pm 1.266$ & 0.23 & 0.41 \\
\hline Cholesterol & 71.77 & 72.83 & 69.46 & 71.83 & 71.50 & $71.48 \pm 1.203$ & 0.85 & 0.77 \\
\hline NUP & 15.53 & 15.91 & 15.37 & 16.87 & 14.66 & $15.67 \pm 0.423$ & 0.79 & 0.38 \\
\hline
\end{tabular}

${ }^{1}$ Standard error; $\hat{Y}=65.738+0.4618 X\left(\mathrm{r}^{2}: 0.84\right)$.

Table 6 - Effect of diets contain different inclusion levels of passion fruit seed meal (PSM), on quantitative carcass traits and organs of pigs in finishing $(60-90 \mathrm{~kg})$.

\begin{tabular}{|c|c|c|c|c|c|c|c|c|}
\hline \multirow{2}{*}{ Item } & \multicolumn{5}{|c|}{ Inclusion levels of PSM (\%) } & \multirow{2}{*}{ Mean $\pm \mathrm{SE}^{1}$} & \multicolumn{2}{|c|}{$p$-value } \\
\hline & 0 & 4 & 8 & 12 & 16 & & $\operatorname{Lin}^{2}$ & Qua $^{3}$ \\
\hline \multicolumn{9}{|c|}{ Quantitative carcass traits } \\
\hline Slaughter weight $(\mathrm{kg})$ & 85.89 & 88.14 & 87.23 & 85.67 & 86.33 & $86.63 \pm 0.512$ & 0.68 & 0.37 \\
\hline Fast break $(\%)$ & 3.948 & 3.714 & 4.089 & 4.178 & 3.815 & $3.954 \pm 0.157$ & 0.85 & 0.68 \\
\hline Hot carcass weight (kg) & 68.87 & 69.17 & 69.23 & 67.78 & 69.31 & $68.86 \pm 0.455$ & 0.86 & 0.88 \\
\hline Hot carcass yield (\%) & 80.26 & 78.47 & 79.37 & 79.10 & 80.28 & $79.50 \pm 0.310$ & 0.81 & 0.06 \\
\hline Cold carcass weight $(\mathrm{kg})$ & 66.81 & 67.44 & 67.29 & 66.00 & 67.66 & $67.02 \pm 0.457$ & 0.94 & 0.81 \\
\hline Cold carcass yield $(\%)$ & 77.84 & 76.51 & 77.12 & 77.01 & 78.36 & $77.37 \pm 0.288$ & 0.50 & 0.06 \\
\hline Yield loss $(\%)$ & 2.987 & 2.506 & 2.824 & 2.609 & 2.558 & $2.703 \pm 0.173$ & 0.53 & 0.82 \\
\hline Abdominal fat $(\mathrm{kg})$ & 0.718 & 0.807 & 0.765 & 0.771 & 0.745 & $0.761 \pm 0.023$ & 0.88 & 0.36 \\
\hline Ham weight $(\mathrm{kg})$ & 10.22 & 10.61 & 10.60 & 10.23 & 10.60 & $10.45 \pm 0.104$ & 0.61 & 0.66 \\
\hline Ham yield (kg) & 30.63 & 31.46 & 31.46 & 30.98 & 31.33 & $31.17 \pm 0.216$ & 0.53 & 0.42 \\
\hline
\end{tabular}


Table 6 - Continued.

\begin{tabular}{|c|c|c|c|c|c|c|c|c|}
\hline \multirow{2}{*}{ Item } & \multicolumn{5}{|c|}{ Inclusion levels of PSM (\%) } & \multirow{2}{*}{ Mean $\pm \mathrm{SE}^{1}$} & \multicolumn{2}{|c|}{$p$-value } \\
\hline & 0 & 4 & 8 & 12 & 16 & & $\operatorname{Lin}^{2}$ & Qua \\
\hline Carcass length $(\mathrm{cm})$ & 89.46 & 88.99 & 88.56 & 89.98 & 88.28 & $89.03 \pm 0.336$ & 0.51 & 0.86 \\
\hline Loin eye area $\left(\mathrm{cm}^{2}\right)$ & 33.64 & 34.74 & 35.69 & 33.78 & 34.84 & $34.54 \pm 0.480$ & 0.67 & 0.46 \\
\hline Fat area $\left(\mathrm{cm}^{2}\right)$ & 13.81 & 15.22 & 14.83 & 15.75 & 13.89 & $14.70 \pm 0.405$ & 0.81 & 0.12 \\
\hline Lean meat $(\mathrm{kg})$ & 50.96 & 53.33 & 53.98 & 51.90 & 54.16 & $52.84 \pm 0.599$ & 0.24 & 0.55 \\
\hline Percentage of lean meat $(\%)$ & 74.11 & 77.08 & 77.90 & 76.68 & 78.19 & $76.77 \pm 0.749$ & 0.14 & 0.42 \\
\hline Meat: fat ratio & 0.417 & 0.440 & 0.422 & 0.469 & 0.405 & $0.431 \pm 0.013$ & 0.92 & 0.34 \\
\hline Relative liver (g/kg) & 1.682 & 1.638 & 1.600 & 1.665 & 1.586 & $1.635 \pm 0.026$ & 0.39 & 0.87 \\
\hline Relative kidney (g/kg) & 0.381 & 0.383 & 0.370 & 0.384 & 0.399 & $0.383 \pm 0.004$ & 0.31 & 0.21 \\
\hline
\end{tabular}

${ }^{1}$ Standard error; ${ }^{2}$ Linear effect of levels of PSM; ${ }^{3}$ Quadratic effect of levels of PSM.

Table 7 - Effect of diets contain different inclusion levels of passion fruit seed meal (PSM) on the qualitative characteristics of pork meat, of pigs in finishing $(60-90 \mathrm{~kg})^{\mathrm{b}}$.

\begin{tabular}{|c|c|c|c|c|c|c|c|c|}
\hline \multirow{2}{*}{ Item } & \multicolumn{5}{|c|}{ Inclusion levels of PSM, \% } & \multirow{2}{*}{ Mean $\pm \mathrm{SE}^{1}$} & \multicolumn{2}{|c|}{$p$-value } \\
\hline & 0 & 4 & 8 & 12 & 16 & & $\operatorname{Lin}^{2}$ & Quad $^{3}$ \\
\hline \multicolumn{9}{|c|}{ Quantitative carcass traits } \\
\hline $\mathrm{pH} 45$ & 6.24 & 6.14 & 6.30 & 6.33 & 6.18 & $6.24 \pm 0.044$ & 0.84 & 0.54 \\
\hline $\mathrm{pH} 24$ & 5.61 & 5.59 & 5.54 & 5.59 & 5.66 & $5.60 \pm 0.032$ & 0.70 & 0.29 \\
\hline Drip loss $(\%)$ & 3.68 & 3.16 & 3.96 & 3.76 & 3.39 & $3.60 \pm 0.176$ & 0.99 & 0.62 \\
\hline Color & 1.93 & 1.92 & 1.93 & 1.73 & 1.71 & $1.85 \pm 0.066$ & 0.18 & 0.67 \\
\hline Marbling & 1.73 & 1.78 & 1.53 & 1.80 & 1.36 & $1.64 \pm 0.071$ & 0.15 & 0.44 \\
\hline Consistency & 2.20 & 2.07 & 2.00 & 2.20 & 2.07 & $2.11 \pm 0.057$ & 0.75 & 0.56 \\
\hline Minolta $L^{*}$ & 46.82 & 49.26 & 48.07 & 47.95 & 47.21 & $47.85 \pm 0.339$ & 0.87 & 0.06 \\
\hline Minolta $a^{*}$ & 6.00 & 6.10 & 5.65 & 5.68 & 6.04 & $5.89 \pm 0.138$ & 0.71 & 0.39 \\
\hline Minolta $b^{*}$ & 4.03 & 4.50 & 3.98 & 4.03 & 4.06 & $4.11 \pm 0.083$ & 0.51 & 0.66 \\
\hline FLT (\%) & 8.36 & 8.17 & 7.74 & 7.75 & 8.17 & $8.03 \pm 0.328$ & 0.72 & 0.55 \\
\hline FLC (\%) & 27.50 & 26.71 & 27.33 & 24.81 & 26.93 & $26.65 \pm 0.387$ & 0.25 & 0.42 \\
\hline $\mathrm{SF}(\mathrm{kgf} / \mathrm{sec})$ & 2.42 & 2.28 & 2.46 & 2.30 & 2.43 & $2.38 \pm 0.047$ & 0.96 & 0.61 \\
\hline
\end{tabular}

${ }^{\mathrm{b}}$ Fluid loss from thawing (FLT), fluid loss from cooking (FLC), $\mathrm{a}^{*}$ indicates the coloration of meat ranging from red to green (high $a^{*}$ value indicates red color, low $a^{*}$ value indicates green color) $b^{*}$ indicates the color of meat ranging from yellow to blue (high $b^{*}$ value indicates tendency to yellow, low $b^{*}$ value indicates tendency to blue), $L^{*}$ indicates the degree of meat lightness $\left(\mathrm{L}^{*}=\right.$ 0 dark meat, L $100=$ white meat) shear force (SF); ${ }^{1}$ Standard error; ${ }^{2}$ linear effect of inclusion levels of FSM; ${ }^{3}$ quadratic effect of inclusion levels of PSM. 
Table 8 - Cost per kilograms of feed, feed cost per kilogram of live weight gain (FC), economic efficiency index (EEI) and cost index (CI) of pigs, during the growing and finishing, fed diets contain different levels of passion fruit seed meal (PSM).

\begin{tabular}{|c|c|c|c|c|c|c|c|c|}
\hline \multirow{2}{*}{ Item } & \multicolumn{5}{|c|}{ Inclusion levels of PSM, \% } & \multirow{2}{*}{$\mathrm{CV}^{1}$} & \multicolumn{2}{|c|}{$p$-value } \\
\hline & 0 & 4 & 8 & 12 & 16 & & Linear & Quadratic \\
\hline \multicolumn{9}{|c|}{ Growing } \\
\hline Initial weight (kg) & 30.45 & 30.79 & 30.59 & 30.56 & 30.67 & - & - & - \\
\hline Finish weight (kg) & 59.83 & 59.53 & 61.63 & 60.17 & 60.62 & - & - & - \\
\hline Feed cost $(\mathrm{R} \$)$ & 0.802 & 0.801 & 0.799 & 0.797 & 0.796 & - & - & - \\
\hline $\mathrm{FC}(\mathrm{R} \$ / \mathrm{kg} \mathrm{PV})$ & 1.875 & 1.861 & 1.848 & 1.850 & 1.828 & 9.07 & 0.47 & 0.98 \\
\hline EEI & 97.53 & 98.24 & 98.95 & 98.86 & 100.00 & - & - & - \\
\hline $\mathrm{CI}$ & 102.53 & 101.79 & 101.06 & 101.15 & 100.00 & - & - & - \\
\hline \multicolumn{9}{|c|}{ Finishing } \\
\hline Initial weight (kg) & 60.37 & 60.57 & 60.36 & 60.36 & 60.36 & - & - & - \\
\hline Finish weight (kg) & 89.47 & 90.19 & 90.95 & 89.46 & 90.09 & - & - & - \\
\hline Feed cost $(\mathrm{R} \$)$ & 0.769 & 0.767 & 0.766 & 0.764 & 0.763 & - & - & - \\
\hline $\mathrm{FC}(\mathrm{R} \$ / \mathrm{kg} \mathrm{PV})$ & 2.314 & 2.305 & 2.284 & 2.294 & 2.225 & 7.66 & 0.21 & 0.62 \\
\hline EEI & 96.15 & 96.53 & 97.40 & 96.97 & 100.00 & - & - & - \\
\hline $\mathrm{CI}$ & 104.00 & 103.59 & 102.67 & 103.13 & 100.00 & - & - & - \\
\hline
\end{tabular}

${ }^{1}$ Coefficient of variation.

\section{CONCLUSION}

The passion fruit seed meal shows 3.244 and $3.223 \mathrm{Mcal} / \mathrm{kg}$ of digestible and metabolizable energy, respectively, and can be added up to $16 \%$ in diets for growing and finishing pigs $(30-90 \mathrm{~kg})$, with possibility of reducing on feed costs.

\section{ACKNOWLEDGEMENTS}

Fruteza-Ltda, for providing the passion fruit seed and to CAPES and CNPq, for the scholarship and research grant.

\section{REFERENCES}

ABIPECS. ASSOCIAÇÃO BRASILEIRA DA INDÚSTRIA PRODUTORA E EXPORTADORA DE CARNE SUÍNA. Estatística de produção. Available at: <http://www.abipecs.org.br/pt/estatisticas/mundial/ producao-2.html $>$ Accessed on: Dez. 01, 2012.

ADEOLA, O.; ILELEJI, K. E. Comparison of two diet types in the determination of metabolizable energy content of corn distillers dried grains with soluble for broiler chickens by the regression method. Poultry Science. 88:579-585, 2009.

ARIKI, J. et al. Aproveitamento de cascas desidratadas e sementes de maracujá (Passiflora edulie f. flavicarpa DEG.) na alimentação de frangos de corte. Científica. 5:340-343, 1977.

BELLAVER, C. et al. Radícula de malte na alimentação de suínos em crescimento e terminação. Pesquisa Agropecuária Brasileira. 20(8):969-74, 1985.

BERTECHINI, A. G. Nutrição de monogástricos. Lavras: UFLA, 2012.

BRIDI, A.M.; SILVA, C.A. Métodos de Avaliação de Carcaça e da Carne Suína. Londrina, 120p. 2009.

CHAU, C. F.; HUANG, Y. L. Characterization of passion fruit seed fibres: a potential fibre source. Food Chemistry. 85(2):189-194, 2004. 
COMA, J.; CARRION, D.; ZIMMERMAN, D.R. Use of plasma urea nitrogen as a rapid response criterion to determine the lysine requirement of pigs. Journal of Animal Science.73:472-481, 1995.

FERRARI, R. A.; COLUSSI, F.; AYUB, R.A. Caracterização de subprodutos da industrialização do maracujá:Aproveitamento das sementes. Revista Brasileira de Fruticultura. 26(1):101-102, 2004.

GOMES J.D.F. et al. Efeito do incremento de fibra dietética sobre a digestibilidade, desempenho e características de carcaça: Suínos em crescimento e terminação. Semina: Ciências Agrárias. 28(3):483-492, 2007.

GOMES, M.F.M. et al. Análise econômica da utilização de triguilho para suínos. Concórdia: EMBRAPACNPSA, p.1-2, 1991, (Comunicado Técnico, 179).

IBGE. Instituto Brasileiro de Geografia e EstatísticaProdução Agrícola Municipal. 2011.

MATTERSON, L.D.; POTTER, L.M.; STUTZ, M.W. The metabolizable energy of feed ingredients for chickens. Storrs, Connecticut University of Connecticut, Agricultural Experiment Station, Research Report. 7(1):11-14, 1965
MORENO, A. M. et al. Colheita e processamento de sangue em suínos para fins de diagnóstico. EMBRAPACNPSA, 1997, 30p. (Documentos, 41).

NELSON, D. L.; MICHAEL, M. C. Princípios de Bioquímica de Lehninger. Porto Alegre, eDITORA aRTMED, 1304P. 2011.

NOBLET, J.; PEREZ, J.M. Prediction of digestibility of nutrients and energy values of pigs diets from chemical analysis. Journal of Animal Science. 71:3389-3398, 1993.

ROSTAGNO, H.S. et al. Tabelas brasileiras para aves e suínos: composição de alimentos e exigências nutricionais. 3.ed. Viçosa: UFV, 2011. 205p.

SAKOMURA, N.K.; ROSTAGNO, H.S. Métodos de pesquisa em nutrição de monogástricos. Jaboticabal: Funep, 2007. 283p.

SILVA, D.J.; QUEIROZ, A.C. Análise de alimentos - métodos químicos e biológicos. 3.ed. Viçosa, Universidade Federal de Viçosa, 2005. 235p.

TOGASHI, C. K. et al. Subprodutos do maracujá em dietas para frangos de corte. Acta Science Animal Science. 30(4):395-400, 2009. 
